\title{
Peculiarities of the transition to the methodological type of university education in different cultures
}

\author{
Mikhail Savelyev ${ }^{1}$, Marina Savelyeva ${ }^{3}$, Natalia Pushina $^{2}$, Tatiana Gruzdeva ${ }^{2}$ and Andrey \\ Savchenko ${ }^{1}$ \\ ${ }^{1}$ Association for Methodological Support of Business Activity and Social Development Mitra, \\ Pushkinskaya 241, Izhevsk, Russia \\ ${ }^{2}$ Kalashnikov Izhevsk State Technical University, Studencheskaya street 7, Izhevsk, Russia \\ ${ }^{3}$ Udmurt State University, 1, Universitetskaya St., bld. 1, 426034 Izhevsk, Russia
}

\begin{abstract}
It was pointed out that there is a need to move from expert to methodological culture in higher professional education. The essence of this way of education is not knowledge about entities, but patterns and tools for knowledge management. The importance of the development of a methodological culture for creating growth areas inside and outside the existing education system and for a fundamental change in the management system of universities is emphasized. The basic models of universities are investigated by the structural method based on the matrix of values of the key cultures of the world. The search for mechanisms of transition to higher methodological education in Russian culture has been carried out. One of the mechanisms of such transformations is the transition to the authentic Russian culture when students select professors and inversed process when professors select students and universities' leadership by the locals.
\end{abstract}

\section{Introduction}

The underlying challenge of higher education is the loss of its defining feature which is its elitism. At present people with higher qualifications, even with the fabulous education provided by the university and supported with their own crafted learning, are not able to discharge their main function which is addressing complex professional problems in each of the four possible object areas of human activity including societal management and control of matter, soul or the person's body. These tasks were aimed at the graduates of the four main faculties of the classical university of the 19th century: Low Faculty, Faculty of Philosophy, Theological Faculty and Medical Faculty. This problem is worldwide and is primarily associated with the accumulation of knowledge and specialization of professional activity. As a result, the skills of university graduates are level with those of graduates of technical schools and enable them to solve narrowly defined tasks under the guidance of a professional of higher qualifications.

"If in the age of enlightenment, scientific languages describing individual objects of study (soul, nature, person's body, society) were the highest linguistic levels of the professional community, cultivated by four faculties of a classical university; and in the 19th century, 
supra-scientific languages of the particular methodologies of each of these scientific languages appeared, which gave rise to the possibility of differentiation of scientific languages and the formation of separate scientific languages of each subject matter; then in the twentieth century, the differentiation of private methodologies began, which put an almost insurmountable barrier on interdisciplinary interaction even between scientific groups researching the same subject, but standing on different methodological foundations, not to mention the highly complex interaction between researchers of different subjects. The scope of scientific (and even more professional) information on each significant subject of research is such that it significantly exceeds the individual capabilities of its acquiring by human beings" - we stated in our previous work [1].

At the moment this issue has no institutionalized solutions for higher education, although there is a theoretically and experimentally implemented solution in the form of the transition to higher vocational training from an expert management culture based on scientific thinking and the characteristic of the agrarian and industrial societies to the methodological culture peculiar to an urbanized society and requiring a completely different space for educational activities than the current one, both in content and methods. The content of methodological teaching should be knowledge itself, with its laws and tools of managing them, and not objects of social, natural or spiritual life. This way implies only active teaching methods, not lectures, seminars, practical classes. This problem was investigated in a number of our works [1-7].

Certain aspects of the problem under consideration are reflected in modern studies.

The importance of the development of a methodological and methodological culture among university students is emphasized, various points of view on the concept of "methodological culture" that have taken place in pedagogy from the middle of the last century to the present are analyzed. For example, the development of a methodological culture among undergraduates is considered as a special focus of the pedagogical concept of the university. At the same time, one of the most important tools for improving the quality of professional training of undergraduates at a university should be research work as a way for students to develop their own methodological culture [8].

The logic of organizing the professional and personal development of bachelors based on of the effective formation of their methodological culture is based on the example of pedagogical education. Attempts are being made to substantiate the essence and structure of the category of methodological culture, as well as to determine its place in the personal development of university students. The methodological basis of such studies is a systematic approach that enables the place of methodological culture in the system of training teachersto-be to be identified and substantiated [9].

The study of the Russian model of a manager when one treated as an altering leader reveals the dependence of the formation of an organizational type of leadership both on continental cultural traditions and on the specifics of the ethnonational culture of the organization. This work shows the shift of manager's competencies from conceptual abilities having come from routine organizational management in the past, to new standards of managerial behavior, in which subordinates are more focused on the transformational leadership model, and the manager focused on the transactional one. This is primarily associated with the management system and cultural values of top management [10].

The globalization, interactions between cultures and civilizations make the heritage of the thinkers of the Russian diaspora extremely relevant today to changes the in social and spiritual situation. Based on a number of works by Bitsilli, and in particular on his work "Nation and Language", Shchedrina I.O. emphasizes the particular relevance of the methodological strategy of the philosopher and the historian, namely the interdisciplinary nature of his research, which is acquiring special semantic content at present, when nation, 
language, culture, as well as their relationship have got new perspectives for consideration in modern sociocultural dynamics [11].

Theories of national information culture are being developed. On the example of studying the influence of Chinese information culture on the perception of information technology by a manager, the differences in the perception and behavior of IT individuals in different cultures are explained. The authors stated that the national information culture awareness provides adequate methodological support for the context of cross-cultural research [12].

\section{Materials and Methods}

Previous studies have shown that in different cultures, economic agents carry out their activities under different principles of social self-determination [7]. This made it possible to classify and order the values of the main cultures of the world. In addition to the scale of interests-bases of decision-making "Individualism - Collectivism" according to [13, 14], the scale "Equality - Inequality" was built, according to which the person's and society's needs were identified:

- Dealing with equal people - equality.

- Dealing with uneven people is inequality.

Thanks to this scaling of target attitudes identified in the course of conceptualizing the principles of social self-determination, a matrix of values for the main cultures of the world was built (Table 1).

Table 1. Types of culture and the structure of social values for the main cultures of the world

\begin{tabular}{|l|c|c|}
\hline $\begin{array}{c}\text { Principles of social } \\
\text { self-determination }\end{array}$ & Equality & Inequality \\
\hline $\begin{array}{l}\text { Individualism is in own } \\
\text { interests }\end{array}$ & $\begin{array}{c}\text { Freedom - Western Culture } \\
\text { Alienating culture }\end{array}$ & $\begin{array}{c}\text { Justice - Middle Eastern and Indian } \\
\text { Cultures } \\
\text { Isolating culture }\end{array}$ \\
\hline $\begin{array}{l}\text { Trust, solidarity - Eastern } \\
\text { interest of the group } \\
\text { European (Eurasian), Latin } \\
\text { American, African, Southeast } \\
\text { Asian cultures } \\
\text { Equalizing culture }\end{array}$ & $\begin{array}{c}\text { Virtue (Mercy and Respect) - East } \\
\text { Asian Culture } \\
\text { Consolidating culture }\end{array}$ \\
\hline
\end{tabular}

Source: [7]

The scale "Individualism - Collectivism" characterizes the self-determination of society concerning the highest criteria for decision-making. The "Equality - Inequality" scale characterizes a reflexive assumption - the basic hypothesis of decision-makers about the reaction of other persons to their decision. If "Equality" is assumed, the decision-makers assume that others react to decision in the same way as themselves, otherwise the decisionmakers expect different reactions from others.

The structural analysis of the well-known concepts of universities regarding this cultural matrix has been carried out in order to identify the mechanisms and bases for new higher methodological education to be developed, including:

- Italian (Bologna) University - University of Student Government,

- $\quad$ French (Sorbonne) - a university that meets a doctrinal order of a state or religious nature, this type includes both Islamic and imperial Russian and Soviet universities,

- $\quad$ English - a university that primarily solves the problem of educating an individual and a citizen (for example, a gentleman) as a worthy representative of the next generation of the ruling elite, 
- German (Humboldt) - a university in which professors and students conduct research together, thereby reproducing the next generation of scientists,

- American - a university, the main customer of which is future employers,

- Japanese - a university that fosters the best team players,

- a regular university that meets the demands for education.

\section{Results and Discussion}

The results of the structural analysis of university models are shown in Table 2.

Table 2. Results of the structural analysis of the concepts of universities by types of cultures.

\begin{tabular}{|l|c|c|}
\hline $\begin{array}{c}\text { Principles of social } \\
\text { self-determination }\end{array}$ & Equality & Inequality \\
\hline Individualism & $\begin{array}{c}\text { University of Elite Education (British } \\
\text { Model) and Equipping Employers with } \\
\text { Skilled Workforce (American Model) }\end{array}$ & $\begin{array}{c}\text { University of Doctrine } \\
\text { Acquiring } \\
\text { (Islamic, Sorbonne and Soviet } \\
\text { models) }\end{array}$ \\
\hline Collectivism & $\begin{array}{c}\text { University of meeting the need for } \\
\text { education and student government } \\
\text { (Bologna and mass models) }\end{array}$ & $\begin{array}{c}\text { Team building university } \\
\text { (German and Japanese models) }\end{array}$ \\
\hline
\end{tabular}

It is only with the Humboldt University model that there are difficulties of classification in the matrix of cultures. On the one hand, it is aimed at forming a scientific elite, and this is similar to the British model. But when applied on a massive scale, it leads to the formation of innovative teams. And by virtue of this feature, this model is classified as a consolidating culture.

For Russian culture, the most consistent are the models of universities, the supreme governing body of which are associations of students and locals. At the same time, with large educational organizations, the competence of the first should be the election of professors, and the second - the management of the university. The professorship should in return receive the right to select students.

The solution to the problem of transition to the methodological type of higher education lies in a fundamental change in the very essence of higher education. If now $90 \%$ of university syllabus are engaged in the study of subjects and only about $10 \%$ - methods of study of knowledge about these subjects, then higher education of the XXI century is education in which $90 \%$ of university disciplines should be devoted to the methods of study of knowledge and only $10 \%$ to subjects of this knowledge.

In this transition from subject-based higher education to methodological education, everyone is equal. Leading universities are even in a less advantageous situation. Their strong professorship allows them to camouflage this problem with copyright courses, personal brands, etc. In provincial universities, under the condition of a weak professorship (for example, in terms of publication activity in publications refereed in WoS and Scopus), this transition can be carried out without much looking back: the formation of a new springboard for a qualitative leap in higher education does not have strong old-fashioned competitors, and a generation change will pass by and large painlessly. Inviting specialists with such technologies for the development of higher education will not be a financial burden even for the meagre funding of a provincial university. To do this, permanent platforms for retraining university teachers and, as teachers master new teaching tools, restructure the composition and content of academic disciplines have to be developed. On the active promotion of 
additional educational services on the market, such a project can give significant additional income.

\section{Conclusions}

In this work, the following conclusions were obtained:

- higher education, as a tool for training professionals capable of treating professional tasks in a holistic manner concerning the entire management object, is now absent as such, and universities now train only mid-level management specialists;

- current higher education is incapable of training senior managers with developed methodological skills in demand in practice since it is initially aimed at training experts whose role in the modern management system is defined as middle and lower management;

- nowadays university graduates, even with the highest quality performance of all educational activities by both students and educational institutions, are not able to discharge their main function - independently deal with complex professional tasks in each of the four possible object areas of human activity, including societal management and control of matter, soul or the person's body;

- the only adequate response to the challenge of the crisis of the dominant expert management culture is the emergence of a methodological culture;

- the content of methodological teaching should be knowledge itself, with its laws and tools of managing them, and not objects of social, natural or spiritual life; methods - only active teaching methods, not traditional lectures, seminars, practical classes;

- the most important national problem of higher education in Russia is the reorientation of universities from supplying the economy with qualified personnel to "meeting the need for education", which for the majority of ill-trained applicants consists solely in obtaining a paper;

- the structure of the distribution of domestic income when incomes in education are below average in the country lets down the level of qualifications in the next generation of professionals. This disables the economy to ensure catch-up development and increases the lag behind the most developed countries of the world, and in the long term is fraught by de-industrialization, a decrease in the standard and quality of life, depopulation and the threat of loss of sovereignty;

- the extensive development of universities, consisting in an increase in the number of students, an increase in the number of specialties and in an increase in the number of universities (including private and branches), has led to the fact that concern for the quality of education has significantly decreased, and the scientific activity of many universities is practically is gone;

- the lack of essence of higher education excludes the possibility of training qualified managers to manage universities. The quality of management, in this case, depends on random, primarily personal factors, and not on the management system;

- in these conditions, the management structure is formed exclusively according to the principles of small business: the powers of top managers are determined by their individual abilities, and not managers are prepared and selected for the purposefully designed functionality of their workplaces and development strategy;

- appointment or election of heads of universities, in which the own attitude and inclination of the head of the region (department, private founder), and even more of the administrative and managerial personnel of the university, are decisive, does not facilitate the connection of universities with real consumers (students, parents of future applicants, employers), does not allow criterion reasonably carry out the selection of candidates, contributes to the cohesion of the management of the university and the 
appointing body to the detriment of the interests of students, employers and the workforce of the university. Appointment of heads of universities based on political criteria moves forward weak leaders who are not able to compete politically with local authority;

- the random nature of the selection of top managers and the non-systemic nature of the management of universities are fraught with abuse in management, corruption of management and teachers which was recorded by law enforcement agencies;

- the lack of a development resource in the regions does not allow either the authorities or large employers to make significant investments in universities, primarily the investments necessary to make a leap in the quality of education. And the actual refusal to invest now casts doubt on the very existence of modern higher education in the region. The summarizing conclusion about the organizational transformations of higher education lies in the need for the transition to an authentic Russian culture of the model of student selection of professors as well as an inversed way when professors select student, and the election of the leadership of universities by the locals.

\section{Acknowledgements}

The reported study was funded by RFBR, project number 20-010-00869

\section{References}

1. M.Yu. Savelyev, M.G. Savelyeva, Bulletin of the Udmurt University, Series "Economics and Law",25(7), 166 (2015)

2. M.Yu. Savelyev, M.G. Savelyeva, Management: theory and practice, 5, 80 (2000)

3. M.Yu. Savelie, Problems of regional economy, 4-5, 164 (2011)

4. M.Yu. Saveliev, Problems of regional economy, 1-2, 315 (2014)

5. M.Yu. Savelyev, Science of Udmurtia, 2(72), 123 (2015)

6. M. Y. Savelyev, Problems of regional economy, 3-4, 133 (2020)

7. M. Y. Savelyev, Multicultural institutionalism: General economic theory of civilizations. The political economy of traditionalism Network Society Project, 488 (2015) http://cognitiofluctus.ru/

8. M.G. Ibragimov, E.G. Vasiliev, International Journal of Educational Sciences, 27(1-3), 23 (2019)

9. A.N. Khodusov, A.A. Khodusov, V.A. Zhabskiy, International scientific and practical conference "Theory and practice of project management in education: horizons and risks" (2020)

10. V.N. Stegnii, L.N. Kurbatova, A.Y. Vnutskikh, K.A., Antipyev, N.V. Viatkina, I.N.Kurbatova, Espacios Sociacion de Profesionales y Tecnicosdel Conicit, 39(19), 30 (2018)

11. I.O. Shchedrina, Vestnik of Saint Petersburg University - philosophy and conflict studies, 36(3), 564 (2020)

12. L. Chen, X. Zhang, Z. Li, Information Technology and People, 33 (1), 56 (2019)

13. R.D. Lewis, When Cultures Collide: Managing Successfully Across Cultures (1996)

14. R.D. Lewis, Business cultures in the international business. From collision to mutual understanding (2001) 